\title{
Hot water dip treatments to destroy Anastrepha obliqua larvae (Diptera: Tephritidae) in mangoes from Puerto Rico'
}

\author{
Alejandro E. Segarra-Carmona,"2 Rosa A. Franqui,", \\ Lucas V. Ramirez-Ramos, ${ }^{3}$ Luis Reynaldo Santiago" \\ and Carlos N. Torres-Rivera:
}

\begin{abstract}
Heated water was probed as a post harvest quarantine treatment to control third instar larvae of the West Indian fruit fly, Anastrepha obliqua (Macquart), in mango, Mangifera indica L., variety Keitt. Fewer larvae infesting 600 to $650 \mathrm{~g}$ fruits survived when mangoes were submerged in water heated to $46.1^{\circ}$ to $46.7^{\circ} \mathrm{C}$ for 20 to 60 minutes. Probit analysis of the data showed that submersion time required to achieve $99.9968 \%$ mortality was $\mathbf{5 9 . 5}$ minutes for mature larvae in fruits.
\end{abstract}

\section{RESUMEN}

Inmersión en agua caliente como tratamiento contra la mosca frutera Anastrepha obliqua en mangó

Se investigó la eficacia letal del agua caliente en mangoes como tratamiento de cuarentena contra larvas del último estado de la mosca frutera, Anastrepha obliqua (Macquart), en mangó (Mangifera indica L.). El tratamiento de frutas infestadas de la variedad Keitt $(600 \mathrm{a} 650 \mathrm{~g}$.) en agua caliente entre 46.1 y $46.7^{\circ} \mathrm{C}$. disminuyó la supervivencia de las larvas en intervalos de inmersión de 20 a 60 minutos. El análisis Probit de los datos demostró que se requieren $\mathbf{5 9 . 5}$ minutos a esta temperatura para asegurar la muerte del $\mathbf{9 9 . 9 9 6 8 \%}$ de las larvas de $\mathbf{A}$. obliqua.

INTRODUCTION

Since the ban of ethylene dibromide (EDB) in 1985, the West Indian fruit fly, Anastrepha obliqua (Macquart), has become the biggest impediment to the exportation of mango fruits from the Caribbean to the mainland (9). For the past 30 years, EDB was a powerful tool used in post harvest control of numerous insect pests, including Anastrepha species in mango. Today, in the absence of $\mathrm{EDB}$, there is no quarantine control treatment for Puerto Rican mangoes.

'Manuscript submitted to Editorial Board 21 February 1990.

${ }^{2}$ Associate Entomologist, Department of Crop Protection.

${ }^{3}$ Research Assistant, Department of Crop Protection.

${ }^{4}$ Trade names in this publication are used only to provide specific information. Mention of a trade name does not constitute a warranty of equipment or materials by the Agricultural Experiment Station of the University of Puerto Rico, nor is this mention a statement of preference over other equipment or materials. 
Anestrepha obliqua was discovered in Puerto Rico in 1891 (5) and has been reported as a pest of mango since the beginning of the century (6, 11). Little information is available on the life history and relative economic status of this fruit fly in mango. This species is widely distributed throughout the Greater and Lesser Antilles, the southern tip of Florida, the Rio Grande Valley in Texas, Mexico, Central America, Venezuela and Brazil $(2,15)$. Its known host range includes almost exclusively Anacardiaceae of fleshy fruit such as mango (Mangifera indica L.), cashew (Anacardium occidentale L.), hog plums (Spondias mombin L.), and "ciruela" (Spondias purpurea L.) (3, 7, 8, 10, 15, 16).

Quarantine security levels for agricultural products with potential for harboring fruit flies were established in 1939 by the United States Department of Agriculture [USDA] (1). This agency established fruit fly quarantine safety at Probit-9 mortality, which is the probability of effectively eliminating $99.99683 \%$ of fruit flies in a given fruit lot without significantly affecting fruit quality. Only fruit treated with methods meeting this USDA quarantine security level would be allowed into the United States.

Presently, hot water-dip treatments constitute the only method allowed by the Animal \& Plant Health Inspection Service (APHIS) for the quarantine security in mangoes. In 1986, Haiti completed quarantine research required by the USDA. The use of lukewarm water $\left(46.1^{\circ} \mathrm{C}\right)$ for 75 minutes resulted in the complete control of Anestrepha suspensa and $A$. obliqua larvae inside Francis, Muscat, Apricot and Jeremie mangoes in that country $(12,14)$. Mexico has been granted permission to export fruit treated for 90 minutes a $46.1^{\circ} \mathrm{C}$ for size 8 mangoes $(600$ to $625 \mathrm{~g})$.

Research conducted by the Puerto Rico Agricultural Experiment Station has demonstrated that hot water-dip treatments appreciably affected neither acceptability nor shelf life of mangoes (4). Consequently, the present work was planned to validate evidence of the efficacy of hot water-dip treatments in eliminating Puerto Rico's strain of West Indian fruit fly larvae in mangoes, an essential step to satisfy USDA requirements on quarantine control of $A$. obliqua in Puerto Rican mangoes.

\section{MATERIALS AND METHODS}

Mature-green No. $\dot{8}$ (600 to $700 \mathrm{~g}$ ) Keitt mangoes were infested in laboratory cages $(35 \times 35 \times 80 \mathrm{~cm})$ each containing 600 to 700 fruit flies. All mangoes used were first quality fruit, freshly picked or taken from the packing lines. Fruits were washed with running water and towel-dried to remove resin deposits. A dozen fruits were kept for $72 \mathrm{~h}$ in each cage for fruit fly infestation. Pulp and exocarp thickness at the fruit's greatest diameter was recorded. Flies used for the infestation were wild flies or first generation descendants. Adult flies were fed with yeast hydroly- 
zate-sugar-powdered milk paste and water, and kept at $27 \pm 1^{\circ} \mathrm{C}$ under a 14:10 (L:D) photoperiod.

After infestation, mangoes were divided at random into two equal groups, a control and a treatment group. Previous development data gathered in our laboratory indicated that all larvae reached third instar 6 to 7 days after oviposition (Segarra \& Torres, unpublished). On the ninth day after infestation, one group of mangoes was subjected to hot water dip treatments inside an 1800-liter stainless steel tank. Water was heated by pressurized vapor, and temperature was maintained at around $46.4^{\circ} \mathrm{C}$ with a thermostatic valve. Water temperature was never lower than $46.1^{\circ} \mathrm{C}$ or higher than $46.7^{\circ} \mathrm{C}$. Water and fruit temperatures were monitored with 38-gauge thermocouples connected to a 16-channel Kaye Digistrip 4M 4 monitor recorder with auto trend. Thermocouple probes size $303(3 \mathrm{~cm})$ were used to monitor internal fruit temperature. Probes were inserted into fruit at its thickest pulp diameter and in contact with the seed. To prevent water seepage, the probe-fruit interphase was sealed with hot plastic. Water temperature was monitored and recorded at intervals ranging from 1 to 5 minutes. Water inside the tank was continuously stirred with two $12.7 \mathrm{~cm}$ propellers operated by a $3 \mathrm{hp}$ motor at high power. Fruits were placed inside a stainless steel basket and submerged in the tank under a heavy load, insuring a minimum of $10 \mathrm{~cm}$ between fruits and top water level.

Treatment time intervals for infested mangoes were $20,30,35,40$, 45, 50 and 60 minutes. Internal fruit temperature was monitored in a separate group of fruits not infested with larvae for 300 minutes posttreatment at room temperature for treatment time intervals of 40,60 and 75 minutes to observe post-treatment heat dissipation.

Mangoes remained undisturbed for 3 to 5 days, after which time fruit was carefully examined for larvae. Fruit examination was conducted in a manner which reduced the possibility of larvae escaping detection. A series of two U.S. Standard Sieves (numbers 10 and 18) followed by a double layer of aluminum screen that covered the sink area where each fruit was examined. Pulp and exocarp were thoroughly examined. To avoid the possibility of reinfestation or the loss of prematurely emerging larvae, we placed treated fruit inside wooden screened cages whose funnel shaped bottoms guided emerging larvae into moist sand trays. The number of live larvae recovered in funnels and from direct examination was recorded.

Probit analysis of our data was performed by Dr. D. A. Wolfenbarger (USDA-ARS-CQFIR, Weslaco, Texas) using Statistical Analysis System Inc. Probit Analysis.

\section{RESULTS AND DISCUSSION}

A total of 22,774 larvae were recovered from the control groups of 
$20,30,35,40,45,50$ and 60 minute tests. The proportion of surviving larvae decreased as time intervals increased (table 1 ). Larval mortality surpassed $93 \%$ after 30 minutes and reached $100 \%$ mortality in 60 minutes. Dead larvae appeared pinkish to brown, with body usually stiff and erect. A single survivor was detected in both the 45 and 50 minute tests, whereas after 40 minutes three larvae survived. Probit analysis indicated that Probit-9 was 59.5 minutes at mean water temperature of $46.4^{\circ} \mathrm{C}$. Lower and upper fiducial confidence limits for this analysis were 49.1 and 80.3 minutes, respectively. These data vary little from those presented by Sharp et al. (14) who found that Probit-9 for Haitian A. obliqua larvae was 58.0 minutes with fiducial lower and upper limits of 47.4 and 84.9 minutes, respectively. The strong resemblance between these results indicates a similar heat response to hot water treatment for both geographical isolates.

Heat penetration into fruit occurred as a quadratic function of time (fig. 1). This quadratic model is in the form of

$$
\mathrm{Y}=77.34+55.24(\mathrm{X})-19.60\left(\mathrm{X}^{2}\right) \text {, with an } \mathrm{R}^{2}=0.98 \text {. }
$$

With this model's prediction, fruit and water temperature would have equilibrated close to 115 minutes at $46.4^{\circ} \mathrm{C}$. Mean internal fruit temperature by the test's end was also a function of treatment time. Mean high temperatures were 41.9 and $42.9^{\circ} \mathrm{C}$ recorded at 50 and 60 minutes, respectively (table 2 ). These figures represent absolute internal fruit temperature of 11.3 and $14.1^{\circ} \mathrm{C}$ from the beginning to the end of treatment tests. Mean pulp thickness for Keitt mangoes used in these experiments was $2.12 \pm 0.25 \mathrm{~cm}(n=60)$.

Post-treatment heat dissipation from fruit was also studied after 40 , 60 , and 75 minutes in $46.4^{\circ} \mathrm{C}$ water. Heat penetration towards the center of the fruit continued for 20 to 25 minutes after treatment termination (fig. 2). This effect was apparent as an increase in internal fruit temperature after mangoes were pulled from the water. The importance of this post-treatment effect in killing larvae is unknown, but it could be an

TABLE 1.-Mortality of Anastrepha obliqua larvae by hot water-dip treatment of infested fruit at various time intervals

\begin{tabular}{cccc}
\hline $\begin{array}{c}\text { Interval } \\
\text { (minutes) }\end{array}$ & $\begin{array}{c}\text { Number of } \\
\text { larvae treated }\end{array}$ & $\begin{array}{c}\text { Number of } \\
\text { larvae killed }\end{array}$ & \% Mortality \\
\hline 20 & 6674 & 4556 & 64.55 \\
30 & 2293 & 2144 & 93.50 \\
35 & 2143 & 2139 & 99.81 \\
40 & 5307 & 5302 & 99.91 \\
45 & 2328 & 2327 & 99.96 \\
50 & 2079 & 2078 & 99.95 \\
60 & 1950 & 1950 & 100.00 \\
\hline
\end{tabular}




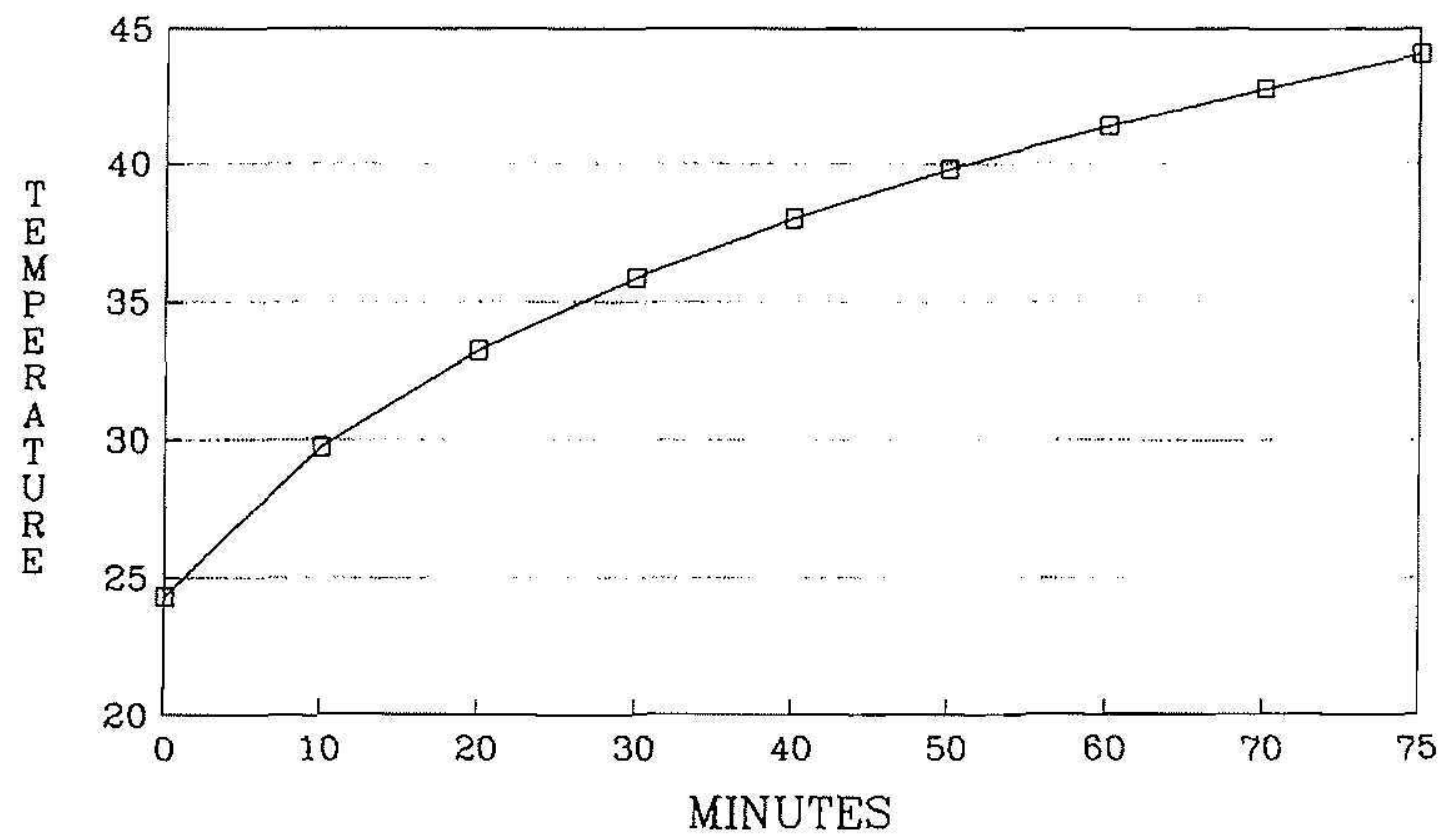

FIG. 1.- Heat penetration curve for uninfected mangoes submerged in hot water $\left(46.1^{\circ}\right.$ to $46.7^{\circ} \mathrm{C}$ ) for 75 minutes. Readings were performed at 10 minute intervals.

essential component of treatment efficacy. Sharp (personal communication) has proposed that this post-treatment period is responsible for the mortality of most larvae and should not be omitted by rapid cooling of the fruit, such as hydrocooling.

It is noteworthy that fruit temperature at the seed surface remains higher than $42.0^{\circ} \mathrm{C}$ for more than half hour after submersion intervals of 60 and 75 minutes. According to Sharp and Chew (13), temperatures below $43.0^{\circ} \mathrm{C}$ do not kill resistant stages (eggs and the first two instars) of $A$. suspensa. If similar heat susceptibility occurs in $A$. obliqua, then a post-treatment waiting period longer than 40 minutes will be ineffective, since internal fruit temperatures would be considerably lower than this lethal temperature.

TABLE 2.-Summary of records for hot water-dip treatments $\left(46.4^{\circ} \mathrm{C}\right)$ conducted in Keitt mangoes from June to September 1988.

\begin{tabular}{lcccc}
\hline $\begin{array}{l}\text { Time } \\
\text { (min.) }\end{array}$ & $\begin{array}{c}\text { No. mangos } \\
\text { infested }\end{array}$ & Mean weight & $\begin{array}{c}\text { Mean high } \\
\text { fruit temp. }\end{array}$ & Mean change \\
\hline & & $g$ & & ${ }^{\circ} \mathrm{C}$ \\
20 & 468 & $621.8 \pm 16.5$ & $33.6 \pm 0.4$ & $+5.2 \pm 0.3$ \\
30 & 228 & $614.8 \pm 16.2$ & $37.0 \pm 0.3$ & $+8.4 \pm 0.3$ \\
35 & 75 & $659.7 \pm 22.0$ & $39.7 \pm 1.3$ & $+9.2 \pm 0.8$ \\
40 & 254 & $613.3 \pm 14.2$ & $39.7 \pm 0.4$ & $+10.8 \pm 0.4$ \\
45 & 75 & $660.5 \pm 17.4$ & $41.3 \pm 0.7$ & $+11.4 \pm 0.8$ \\
50 & 114 & $660.4 \pm 17.6$ & $41.9 \pm 0.3$ & $+11.3 \pm 0.3$ \\
60 & 224 & $615.9 \pm 16.8$ & $42.7 \pm 0.2$ & $+14.1 \pm 0.2$ \\
\hline
\end{tabular}




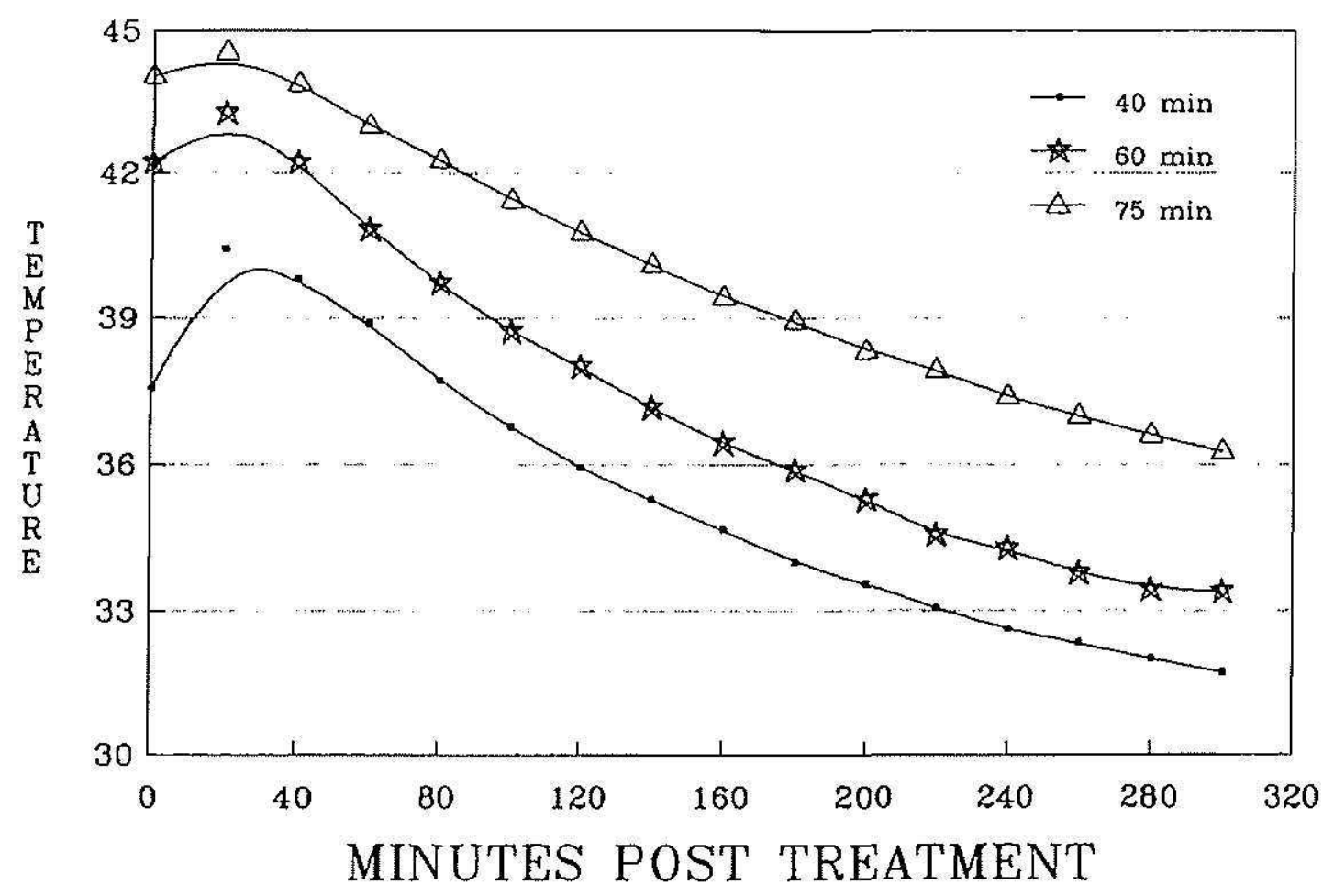

FIG. 2.-Post treatment heat dissipation curves for uninfected mangos after hot water dip treatment intervals of 40,60 and 75 minutes.

Mangoes treated with hot water dips normally did not show phytotoxic effects. Treated mangoes showed color 1 to 2 days ahead of controls, and ripened with high uniformity, a trait not observed in the controls. Two observations made from treated fruit involved proper maturity stage and fruit quality. Mangoes picked too green (pulp still not showing a light yellow color) shriveled and pitted; hot water-dip treatments appeared to increase visibility of fruit blemishes. This observation should caution producers to monitor picking and packing operations closely, paying special attention to fruit ripeness and quality.

\section{LITERATURE CITED}

1. Baker, A. C., 1939. The basis for treatment of products where fruit flies are involved as a condition for entry into the United States. USDA Circular 551.

2. - W. E. Stone and C. C. Plummer, 1944. A review of studies on the Mexican fruitfly and related Mexican species. USDA Misc. Publ. 531.

3. Costa Lima, A., 1934. Moscas de frutas de genero Anastrepha Schiner, 1868. Memorias do instituto Oswaldo Ruiz. Rio de Janeiro, Brasil.

4. Díaz, N., T. Rodríguez and I. B. de Caloni, 1988. Shelf-life and acceptability of hot water-treated mangoes. J. Agric. Univ. $P, R, 72: 469-74$.

5. Gundlach, J., 1891. Apuntes para la fauna Puertorriqueña. Anales de la Sociedad Española de Historia Natural. 20: 109-381.

6. Hooker, C. W., 1913. Report of the entomologist. Annual Report. P. R. Agric. Exp. Stn. 1912: 34-6.

7. Nascimento, A. S., R. C. Caldas and L. M. Silva, 1983. Bioecologia das Moscas-das- 
frutas Anastrepha spp. Relatorio tecnico anual do Centro Nacional de Pesquisa de Mandioca e Fruticultura. EMBRAPA. 1982 Report. pp. 80-3.

8. - R. A. Zucchi and S. Silveira-Neto, 1983. Dinamica populacional das moscas-dasfrutas no reconcavo baiano. III. Analise Faunistica. Pesq. Agropec. Bras. 18: 319-28.

9. Ruckelshaus, W. D., 1984. Ethylene dibromide, amendment of notice of intent to cancel registration of pesticide products containing ethylene bromide. Fed. Regist. 49 (70): 14182-85.

10. Sein, F., Jr., 1933. Anastrepha (Trypetydae, Diptera) fruit flies in Puerto Rico. $J$. Agric. Univ. P. R. 17: 183-96.

11. Segarra-Carmona, A. E., 1988. Identity and importance of fruit flies attacking mango in Puerto Rico. J. Agric. Univ. P. R. 72: 325.

12. Sharp, J. L., 1986. Hot water treatment for the control of Anastrepha suspensa (Diptera: Tephritidae). J. Econ. Entomol. 79: 706-08.

13. — and V. Chew, 1987. Time/mortality relationships for Anastrepha suspensa (Diptera:Tephritidae) eggs and larvae submerged in hot water. J. Econ. Entomol. 80: 646-49.

14. - M. T. Ouye, R. Thalman, W. Hart, S. Ingle and V. Chew, 1988. Submersion of 'Francis' mango in hot water as a quarantine treatment for the West Indian fruit fly and the Caribbean fruit fly (Diptera: Tephritidae). J. Econ. Entomol. 81: 1431-436.

15. Stone, A., 1942. The fruitflies of the genus Anastrepha. USDA. Misc. Publ. No. 439.

16. Wolcott, G. N., 1948. The insects of Puerto Rico, J. Agric. Univ. P. R. 32: 1-975. 